\title{
Bio-Diversity of Lactobacillus Cultures Associated with the Traditional Ethnic Fermented Foods of West Garo Hills, Meghalaya, India
}

\author{
Birendra Kumar Mishra ${ }^{1}$, Subrota Hati ${ }^{2}$, Sujit Das ${ }^{1}$ and Keyur Patel ${ }^{2}$ \\ ${ }^{1}$ Department of Rural Development and Agricultural Production, North-Eastern Hill University, \\ Tura campus, Meghalaya-794 001, India \\ ${ }^{2}$ Dairy Microbiology Department, S.M.C. College of Dairy Science, Anand Agricultural \\ University, Anand-388 110, India \\ *Corresponding author
}

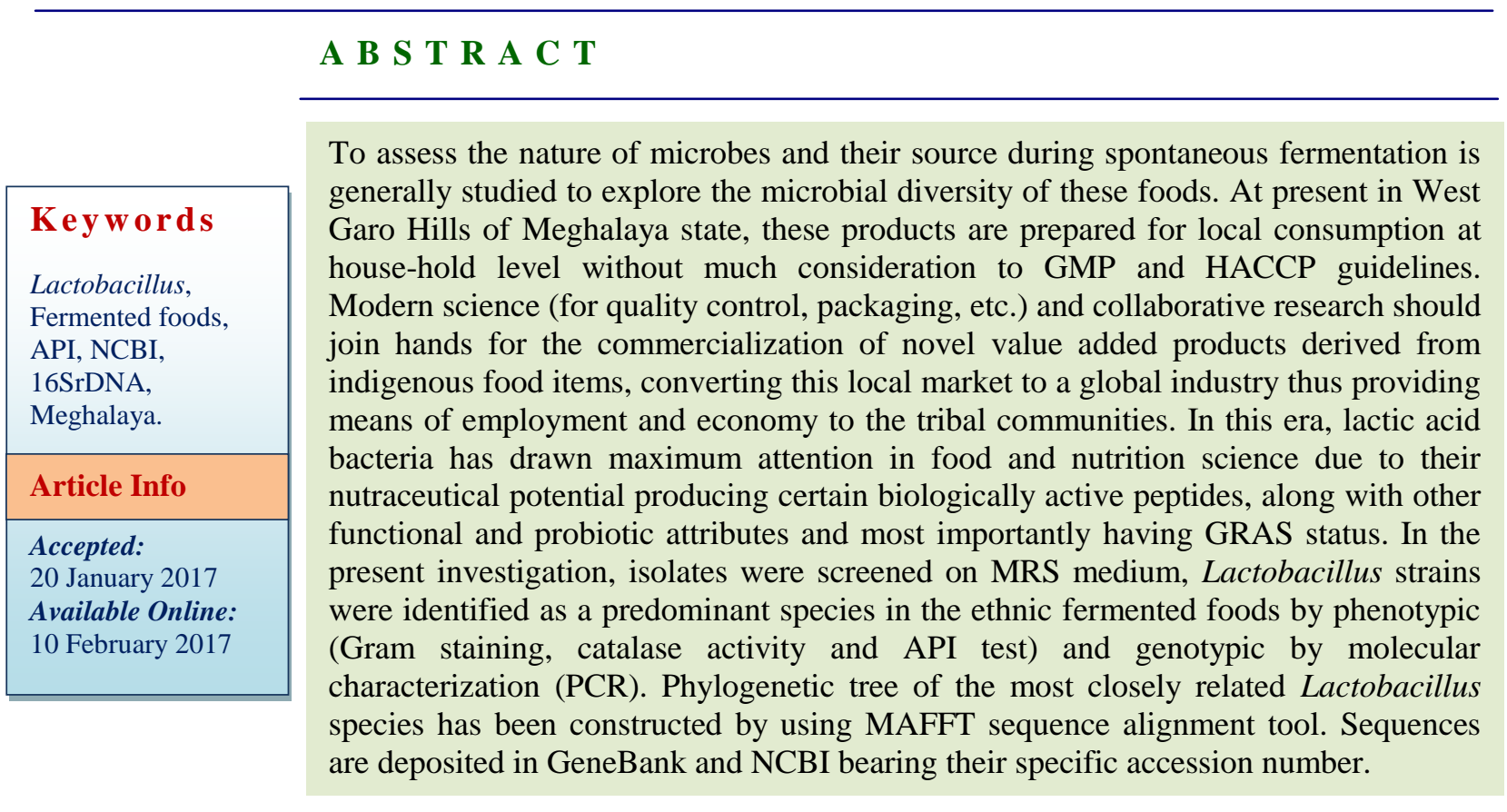

\section{Introduction}

West Garo Hills, Meghalaya (North East region of India) is characterized by a diverse population of tribal people (Garos, Khasis, Jaintias etc) with different ethnic background. Most of the people of this region are tribal and bear their own methods of fermenting food materials for the purpose of preservation and taste enhancement. All the fermented products are region specific and have their own unique substrates and preparation methods (Das and Deka, 2012). Materials such as soybeans, fish, curd, beverages and locally available vegetables are commonly fermented by most of the tribes. Traditional fermentation is a form of food processing, where microbes, for example, lactic acid bacteria (LAB) are utilized. The bacteria use food as a substrate for their propagation. Over the years, it became part of the cultural and traditional norm among the indigenous 
communities (Chelule and Laleye, 2010). The rural folk have come to prefer fermented over the unfermented foods because of their pleasant taste, texture and colour. This popularity has made fermented foods one of the main dietary components of the developing world (Aderiye et al., 2003; Mosha et al., 2004; Nout et al., 1999). The traditional way of carrying out fermentation at the household-scale is still followed using relatively simple processing facilities. These products often contain mixed microbial populations because of the lack of sterility and the use of natural fermentation (Nout et al., 1999). The people of this particular state have a very rich reserve of traditional knowledge owing to their livelihood in the hilly terrains. This area is inhabited largely by tribal people who make up $75 \%$ of the population of the region (Agrahar-Murungkar and Subbulakshmi, 2006). These people possess great knowledge of the environment and depend on the forests, plants and plant products for food and other purposes (Jaiswal et al., 2010).

Being one of the oldest tribes of India as well as of North East, the people of Meghalaya have a different taste and recipe which is a special feature of the region. The recipe known as the Nakhem or Hindal of Meghalaya is a delectable soup which is very popular among them. The Nakham is basically a special dry fish which is used to make the soup. The fresh fish is dried under the sun or over the fire first. Once the fish gets completely dried, it is mixed up with alkali, ginger, onion and salt, placed inside bamboo tube, the mouth of the tube covered with plantain leaves and made tight with thin bamboo slivers. The most preferred fish curry T'pai bamsi is prepared by rice powder, alkali and pulse (Phaseolus radiatus) along with Hindal. Sometime, small snails (Neguria) are also added to make the dish tastier. Lots of chilly and other spices are used to enhance the taste of the soup (Gitanjali and Mandal, 2015).

Alcoholic rice beverages are an integral part of life of several aboriginal communities and are known in different names in different places. It is known as sake in Japan, laochaoin China, tape ketan in Indonesia, khaomak in Thailand (Devi et al., 2015). In India, an alcoholic beverage called sura distilled from rice was in use between 3000 and 2000 B.C. Similarly, in the state of Meghalaya in India, the Garo tribal community has a distinct food culture or dietary culture which is paramount to their diet is $c h u-a / s$ which is an alcoholic rice beverage that symbolizes the heritage and socio cultural aspects of their ethnicity.

Fermented rice, wanti is prepared by adding water to cooked rice and incubating the mixture overnight. The water is drained off and used to cook vegetables or mixed with buttermilk and salt for direct consumption. Rice is mixed with dahi and salt. Strains of Pediococcus, Lactobacillus and Streptococcus have been isolated previously from fermented rice. The $\mathrm{pH}$ is decreased from 6.1 to 5.7 in $16 \mathrm{hrs}$. There is no change in volume, amino nitrogen or free sugar (Steinkraus, 1996).

Traditionally, Dahi is a naturally fermented milk product obtained from boiled cow or buffalo milk and soured using lactic cultures as Lactococcus lactis spp., Lactococcus lactis spp. cremoris, and L. diacetylactis it used separately or in combination. It is used in daily diet as a potential source of B-complex vitamins, folic acid, and riboflavin (Sarkar et al., 2015).

This study deals with the isolation and identification of the predominant species of Lactobacillus in naturally fermented foods of Meghalaya, India. Phenotypic and genotypic characterization was carried out respectively for confirmation of genus and species level of 
Lactobacillus strains, along with DNA sequencing and analysis of phylogenetic studies by utilizing $16 \mathrm{~S}$ rRNA gene (Fig. 3).

\section{Materials and Methods}

\section{Sample collection and bacterial growth enrichment}

Homemade and commercial samples of fermented foods (Fig. 1) were collected from different region of Meghalaya state and included in this investigation (Table 1). The enrichment process was carried out by inoculating approximately $1 \mathrm{ml}$ of a mix of the fermented food samples and poured into $50 \mathrm{ml}$ sterile MRS broth (HiMedia, India) and incubated at $37^{\circ} \mathrm{C}$ for (2-5) days (Abbas and Mahasneh, 2014). All samples were collected into sterile glass bottles and were kept in the laboratory at refrigeration temperature (4-6 ${ }^{\circ} \mathrm{C}$ ) for further analysis.

\section{Isolation and purification of Lactobacillus strains}

Enriched fermented food samples were serially diluted in sterile normal saline. Aliquots of $100 \mu \mathrm{l}$ from each dilution were then plated on MRS media supplemented with $0.01 \%$ bromocresol purple as a $\mathrm{pH}$ indicator. Plates were incubated at $37^{\circ} \mathrm{C}$ for 24 hours. Presumptive Lactobacillus colonies with yellow halos were randomly picked up from the MRS plates and were further subcultured onto fresh plates of the same medium to ensure purity.

\section{Identification of bacterial Strains}

All isolates were tested for catalase activity, Gram reaction (Fig. 2) and cell morphology (Guessas and Khal, 2004). The identification of strains was performed according to their morphological, cultural and biochemical properties based on their specific characteristics as described in Bergy's manual (Buchanan and Gibbons, 1974). The strains were tested for the production of acids from carbohydrates and related compounds using API $50 \mathrm{CH}$ kits (HiMedia, India) according to the manufacturer's instructions. Results were scored after incubation at $37^{\circ} \mathrm{C}$ for 24 and 48 hours. These results were put on the apiweb ${ }^{\mathrm{TM}}$ identification software with database (V5.1) which uses the phenotypic data to predict a species identity. Interpretations of the fermentations profiles were facilitated by comparing all results obtained for the tested isolates with information from the computer aided database, apiweb ${ }^{\mathrm{TM}}$ (https://apiweb.biomerieux.com).

Confirmation of lactobacilli isolates by colony PCR

Molecular characterization of isolates was done by Polymerase Chain Reaction (PCR) using primers (27F and 1492R) (Table 2). Template was prepared by picking freshly grown colony and transferred to TE buffer and incubate at $80^{\circ} \mathrm{C}$ for 15 minutes. This was further amplified by PCR and confirmed by running product on agarose gel $(1 \%)$ in gel electrophoresis.

PCR mixture was initially heated at $94^{\circ} \mathrm{C}$ for 5 minutes followed by cycles of denaturation at $94^{\circ} \mathrm{C}$ for $1 \mathrm{~min}$, annealing $56^{\circ} \mathrm{C}$ for $1 \mathrm{~min}$ and extension was performed at $72^{\circ} \mathrm{C}$ for 5 minutes.

\section{Phylogenetic analysis}

To determine the closest known relatives of the partial 16S rDNA sequences obtained, nucleotide database searches were performed in NCBI GenBank and later the sequences were analysed by multiple sequence alignment tools using the DNA alignment program MAFFT v6.864 to signify the evolutionary relatedness (Fig. 4) between the 
strains by UPGMA (Unweighted Pair Group Method with Arithmetic Mean)

\section{Results and Discussion}

This study was conducted to isolate Lactobacillus strains from various ethnic fermented foods (Fig. 1) (fermented fish, fermented rice and rice beverages, curd samples) from the various places of Meghalaya (North-eastern region of India) and explore their phenotypic and genotypic characteristics for further, development of value added products by identifying productive microbial strains.

\section{Phenotypic characterization Lactobacillus strains}

of

A total of nine strains were isolated from the various fermented food samples obtained from different places of Meghalaya, India (Table 1). Nine catalase negative and Gram positive bacteria were isolated from traditional fermented foods and considered as presumptive LAB (Fig. 2). Further, biochemical tests of all the isolates were carried out by API CH 50 Microbial Identification kit (bioMerieux, India) through sugar fermentation pattern, ammonia production from arginine, gas production from glucose were carried out for the initial characterisation of lactic acid bacteria isolated from the samples.

K7, K8, K10, K11, K14 showed positive whereas K3A, K4E, K5, K6 showed negative test results for L-arabinose respectively. K3A, K4E, K5, K6, K7, K8, K10 and K11 showed positive whereas K14 showed negative results for D-ribose, D-galactose, D-fructose, Dmannose, D-trehalose, Esculin ferric citrate, D-maltose, D-saccharose respectively (Table 3). K8 and K11 showed positive whereas $\mathrm{K} 3 \mathrm{~A}, \mathrm{~K} 4 \mathrm{E}, \mathrm{K} 5, \mathrm{~K} 6, \mathrm{~K} 7, \mathrm{~K} 10$ and K14 showed negative results for D-xylose respectively. K4E and $\mathrm{K} 7$ showed positive whereas K3A, K5, K6, K8, K10, K11 and K14 showed negative test results for L-sorbose respectively. K6 and $\mathrm{K} 7$ showed positive whereas K3A, K4E, K5, K8, K10, K11 and K14 showed negative results for Rhamnose respectively. K4E showed positivity whereas as K3A, K5K6, K7, K8, K10, K11 and K14 showed negative results for Dulcitol respectively. $\mathrm{K} 4 \mathrm{E}, \mathrm{K} 7, \mathrm{~K} 8, \mathrm{~K} 10$ and $\mathrm{K} 11$ showed positive whereas $\mathrm{K} 3 \mathrm{~A}, \mathrm{~K} 5, \mathrm{~K} 6$ and K14 showed negative results for D-mannitol, D-melezitose, Salicin, D-Celibiose and Arbutin respectively. K4E, K7, K8 and K10 showed positive whereas K3A, K5, K6, K11 and K14 showed negative results for Dsorbitol respectively. K8 showed positivity whereas K3A, K4E, K5, K6, K7, K10, K11 and K14 showed negative results for methyl $\alpha$-D-glucopyranoside. K7, K11, K14 showed positive whereas $\mathrm{K} 3 \mathrm{~A}, \mathrm{~K} 4 \mathrm{E}, \mathrm{K} 5, \mathrm{~K} 6, \mathrm{~K} 8$ and K10 showed negative results for methyl- $\alpha$-Dmannopyranoside respectively.

K4E, K7, K8, K10, K11 and K14 showed positive whereas K3A, K5, K6 exhibited negative results for $\mathrm{N}$-acetyl glucosamine respectively. $\mathrm{K} 7, \mathrm{~K} 8, \mathrm{~K} 10, \mathrm{~K} 11$, K14 showed positive whereas, K3A, K4E, K5, K6 showed negative for amygdalin respectively. K10 showed positive whereas K3A, K4E, K5, K6, K7, K8, K11, K14 exhibited negative for raffinose respectively. $\mathrm{K} 7, \mathrm{~K} 10, \mathrm{~K} 11$ showed positive whereas $\mathrm{K} 3 \mathrm{~A}, \mathrm{~K} 4 \mathrm{E}, \mathrm{K} 5$, K6, K8, K14 showed negative for D-turanose respectively. K4E, K7, K8, K11 showed positive whereas $\mathrm{K} 3 \mathrm{~A}, \mathrm{~K} 5, \mathrm{~K} 6, \mathrm{~K} 10, \mathrm{~K} 14$ showed negative results for D-tagatose respectively. K8 and $\mathrm{K} 14$ showed positive whereas K3A, K4E, K5, K6, K7, K10, K11 showed negative results for potassium gluconate respectively. All the nine isolates were able to utilize D-glucose and D-lactose and all the nine isolates were unable to utilize Glycerol, Erythritol, D-arabinose, L-xylose, Methyl- $\beta$-D-xylopyranoside, D-adonitol, 
Inositol, Starch, Inulin, D-adonitol, L-fucose, D-fucose, D-arbitol, D-lyxose, Glycogen, Xylitol, and Potassium-5-ketogluconate thereby resulting to be negative respectively. Previously, Krischina et al., (2014) carried out the phenotypic identification for Lactobacillus isolates from the Brazilian grape sourdough which was performed by using the kit API50 CHL. Dilek et al., (2011) reported identification of Lactobacillus strains isolated from faecal specimens of babies and human milk colostrum by API $50 \mathrm{CHL}$ system. Similarly, Suk et al., (2012) investigated the isolation and characterization of lactic acid bacteria (LAB) from naturally fermented sauce-type kimchi. Hence, from the above biochemical tests it was assumed that all the eight isolates belonged to the group of heterofermentative (K3A, K4E, K5, K6, K7, $\mathrm{K} 8, \mathrm{~K} 10, \mathrm{~K} 11)$ and one was categorized under homofermentative (K14) lactic acid bacteria. The tentative identification by using API 50 $\mathrm{CH}$ was in good concordance with those by the genetic identification further.

\section{Molecular confirmation and 16S rDNA sequence analysis of Lactobacillus strains}

Easiest and simplest way for identification of LAB is amplification of 16S rRNA, 16S-23S intergenic spacer region (ISR), or 23S rRNA universal gene by designing specific primers (Kim et al., 2005). In the present study, primer $27 \mathrm{~F}$ and $1492 \mathrm{R}$ were used for amplification conserved regions of $16 \mathrm{~S}$ rRNA, resulted in product of $1.5 \mathrm{~kb}$ fragments confirming that the isolate bacteria was from genus Lactobacillus. Rahayu et al., (2009) used same primers set for amplification of bacterial 16S rRNA gene and reported the PCR product of $1.5 \mathrm{kbs}$.

A similar study was executed by Crispim et al., (2013) where the genomic diversity of Lactobacillus spp. from puba, a Brazilian fermented cassava food, was investigated by molecular typing with rep (repetitive sequence)-based PCR using the primer ERIC2. Adeymo et al., (2014) similarly reported the characterisation of Lactobacillus plantarum using molecular methods by polymerase chain reaction (PCR) and amplification of 16S rDNA genes to confirm their identities from fermented cereals. Direct amplification of 16S-23S intergenic space regions (ISRs) or PCR with specific primer derived from L-ISR was reported to be useful for specific typing of Lactobacillus sanfranciscensis (Valcheva et al., 2006).

The electrophenogram data for 16S rDNA sequence was validated using Chromas 2.33 software. Sequences obtained were matched with previously published bacterial $16 \mathrm{~S}$ rDNA sequences available in the GenBank database using BLAST. The sequences determined in this study have been deposited in the NCBI GenBank database with accession numbers (Table 4).

\section{Phylogenetic analysis}

From the following phylogram, it can be stated that the four isolates of Lactobacillus fermentum are closely related due to the sequence similarity match as well the nodal distance. The other distantly related isolate is of Lactobacillus rhamnosus that connects the branch of the four closely related Lactobacillus fermentum strains.

Similar work has been reported by Claesson et al., (2008) selecting 12 genomes of Lactobacillus strains which were further subjected to an array of whole-genome and single-marker phylogenetic approaches, to investigate the case for extracting subgeneric groups and to determine whether a single congruent phylogeny could be identified. Ennahar et al., (2003) also reported the phylogenetic diversity of Lactic Acid Bacteria associated with paddy rice silage. The 
evolutionary relatedness is also revealed by the similarity match of the three strains of Lactobacillus plantarum. Lactobacillus helveticus is however distantly related from the other strains of Lactobacills spp. as revealed by the dendogram and its distantly located branch. Each node with descendants represents the inferred most recent common ancestor of the descendants which in this case is Lactobacillus.

Table.1 List of selected isolates with their phenotypical characterization

\begin{tabular}{|c|c|c|c|c|c|c|c|}
\hline $\begin{array}{l}\text { Sl. } \\
\text { No. }\end{array}$ & $\begin{array}{l}\text { Fermented } \\
\text { Food } \\
\text { Sample }\end{array}$ & $\begin{array}{c}\text { Traditional } \\
\text { name of } \\
\text { collected } \\
\text { fermented food } \\
\text { sample }(\mathbf{s})\end{array}$ & $\begin{array}{c}\text { Place of } \\
\text { purchased } \\
\text { fermented } \\
\text { food } \\
\text { sample (s) }\end{array}$ & $\begin{array}{l}\text { Isolate } \\
\text { Code }\end{array}$ & $\begin{array}{l}\text { Morphological } \\
\text { characteristics }\end{array}$ & $\begin{array}{c}\text { Gram's } \\
\text { Reaction }\end{array}$ & $\begin{array}{l}\text { Microscopic } \\
\text { Examination }\end{array}$ \\
\hline 1 & $\begin{array}{l}\text { Fermented } \\
\text { Fish }\end{array}$ & Nakham & $\begin{array}{l}\text { Tura, West } \\
\text { Garo Hills }\end{array}$ & K3A & $\begin{array}{l}\text { Small, } \\
\text { translucent }\end{array}$ & positive & Bacilli \\
\hline 2 & $\begin{array}{l}\text { Fermented } \\
\text { Fish }\end{array}$ & Nakham & $\begin{array}{c}\text { Zanjal, } \\
\text { West Garo } \\
\text { Hills } \\
\end{array}$ & K4 & $\begin{array}{l}\text { Medium, flat, } \\
\text { entire, } \\
\text { translucent }\end{array}$ & positive & Bacilli \\
\hline 3 & $\begin{array}{l}\text { Fermented } \\
\text { Fish }\end{array}$ & Nakham & $\begin{array}{c}\text { Rajabala, } \\
\text { West Garo } \\
\text { Hills }\end{array}$ & K5 & $\begin{array}{l}\text { Small, entire, } \\
\text { translucent }\end{array}$ & positive & Bacilli \\
\hline 4 & $\begin{array}{l}\text { Local curd } \\
\text { sample }\end{array}$ & Dahi & $\begin{array}{l}\text { Sohra, } \\
\text { Shillong }\end{array}$ & K6 & $\begin{array}{l}\text { Small, entire, } \\
\text { rough,translucent }\end{array}$ & positive & Bacilli \\
\hline 5 & $\begin{array}{l}\text { Local curd } \\
\text { sample }\end{array}$ & Dahi & $\begin{array}{l}\text { Asanang, } \\
\text { Garo Hills }\end{array}$ & K7 & $\begin{array}{l}\text { Medium, entire, } \\
\text { rough translucent }\end{array}$ & positive & Bacilli \\
\hline 6 & $\begin{array}{l}\text { Fermented } \\
\text { Rice }\end{array}$ & Wanti & $\begin{array}{c}\text { Achetra, } \\
\text { West Garo } \\
\text { Hills }\end{array}$ & K8 & Small pinpoint & positive & Bacilli \\
\hline 7 & Rice beer & chu-a/s & $\begin{array}{c}\text { Achetra, } \\
\text { West Garo } \\
\text { Hills }\end{array}$ & K10 & $\begin{array}{l}\text { Pinpoint, } \\
\text { transperant }\end{array}$ & positive & Bacilli \\
\hline 8 & Rice beer & chu-a/s & $\begin{array}{c}\text { Sahaki, } \\
\text { West Garo } \\
\text { Hills }\end{array}$ & K11 & $\begin{array}{l}\text { Pinpoint, } \\
\text { transperant }\end{array}$ & positive & Bacilli \\
\hline 9 & $\begin{array}{l}\text { Fermented } \\
\text { fish }\end{array}$ & Hindal & $\begin{array}{l}\text { Asanang, } \\
\text { Garo Hills }\end{array}$ & K14 & $\begin{array}{l}\text { Pinpoint, } \\
\text { transperant }\end{array}$ & positive & Bacilli \\
\hline
\end{tabular}

Table.2 Oligonucleotide sequences for PCR amplification

\begin{tabular}{|c|c|}
\hline \multicolumn{2}{|c|}{ Primers } \\
\hline $27 \mathrm{~F}$ & 5' TACGGYTACCTTGTTACGACTT 3' \\
\hline 1492 R & 5' AGAGTTTGATCAMTGGCTCAG 3' \\
\hline
\end{tabular}


Table.3 Biochemical tests of screened isolates through API 50CH kit

\begin{tabular}{|c|c|c|c|c|c|c|c|c|c|c|}
\hline \multicolumn{2}{|r|}{ API $50 \mathrm{CH}$} & 1 & 2 & 3 & 4 & 5 & 6 & 7 & 8 & 9 \\
\hline 0 & Control & - & - & - & - & - & - & - & - & - \\
\hline 1 & Glycerol & - & - & - & - & - & - & - & - & - \\
\hline 2 & Erythritol & - & - & - & - & - & - & - & - & - \\
\hline 3 & D-Arabinose & - & - & - & - & - & - & - & - & - \\
\hline 4 & L-Arabinose & - & - & - & - & + & + & + & + & - \\
\hline 5 & D-Ribose & + & + & + & + & + & + & + & + & - \\
\hline 6 & D-Xylose & - & - & - & - & - & + & - & + & - \\
\hline 7 & L-Xylose & - & - & - & - & - & - & - & - & - \\
\hline 8 & D-Adonitol & - & - & - & - & - & - & - & - & - \\
\hline 9 & Methyl $\beta$-D-Xylopyranoside & - & - & - & - & - & - & - & - & - \\
\hline 10 & D-Galactose & + & + & + & + & + & + & + & + & - \\
\hline 11 & D-Glucose & + & + & + & + & + & + & + & + & + \\
\hline 12 & D-Fructose & + & + & + & + & + & + & + & + & - \\
\hline 13 & D-Mannose & + & + & + & - & + & + & + & + & - \\
\hline 14 & L-Sorbose & - & + & - & - & + & - & - & - & - \\
\hline 15 & L-Rhomnose & - & - & - & - & + & + & - & - & - \\
\hline 16 & Dulcitol & - & + & - & - & - & - & - & - & - \\
\hline 17 & Inositol & - & - & - & - & - & - & - & - & - \\
\hline 18 & D-Mannitol & - & + & - & - & + & + & + & + & - \\
\hline 19 & D-Sorbitol & - & + & - & - & + & + & + & - & - \\
\hline 20 & $\begin{array}{l}\text { Methyl } \alpha \text {-D- } \\
\text { Mannopyranoside }\end{array}$ & - & - & - & - & + & - & + & + & - \\
\hline 21 & Methyl $\alpha$-D-Glucopyranoside & - & - & - & - & - & + & - & - & - \\
\hline 22 & N-Acetyl Glucosamine & - & + & - & - & + & + & + & + & + \\
\hline 23 & Amygdalin & - & - & - & - & + & + & + & + & - \\
\hline 24 & Arbutin & - & + & - & - & + & + & + & + & - \\
\hline 25 & Esculin Ferric citrate & + & + & + & + & + & + & + & + & - \\
\hline 26 & Salicin & - & + & - & - & + & + & + & + & - \\
\hline 27 & D-Celiobiose & - & + & - & - & + & + & + & + & - \\
\hline 28 & D-Maltose & + & + & + & + & + & + & + & + & - \\
\hline 29 & $\begin{array}{l}\text { D-Lactose } \\
\text { (bovine origin) }\end{array}$ & + & + & + & + & + & + & + & + & + \\
\hline 30 & D-Melibiose & + & + & + & + & + & + & + & + & - \\
\hline 31 & $\begin{array}{l}\text { D-Saccharose } \\
\text { (Sucrose) }\end{array}$ & + & + & + & + & + & + & + & + & - \\
\hline 32 & D-Trehalose & + & + & + & + & + & + & + & + & - \\
\hline 33 & Inulin & - & - & - & - & - & - & - & - & - \\
\hline 34 & D-Melezitose & - & + & - & - & + & + & + & + & - \\
\hline 35 & D-reffinose & + & + & + & + & + & + & - & + & + \\
\hline 36 & Amidon(starch) & - & - & - & - & - & - & - & - & - \\
\hline 37 & Glycogen & - & - & - & - & - & - & - & - & - \\
\hline
\end{tabular}




\begin{tabular}{|l|l|c|c|c|c|c|c|c|c|c|}
\hline 38 & Xylitol & - & - & - & - & - & - & - & - & - \\
\hline 39 & Gentiobiose & - & + & - & - & + & - & + & + & - \\
\hline 40 & D-Turanose & - & - & - & - & + & - & + & + & - \\
\hline 41 & D-Lyxose & - & - & - & - & - & - & - & - & - \\
\hline 42 & D-Tagatose & - & + & - & - & + & + & - & + & - \\
\hline 43 & D-Fucose & - & - & - & - & - & - & - & - & - \\
\hline 44 & L-Fucose & - & - & - & - & - & - & - & - & - \\
\hline 45 & D-Arbitol & - & - & - & - & - & - & - & - & - \\
\hline 46 & L-Arbitol & - & + & - & - & - & + & - & - & - \\
\hline 47 & Potassium Gluconate & + & + & + & + & + & - & + & + & - \\
\hline 48 & Potassium2-KetoGluconate & - & - & - & - & - & - & - & - & - \\
\hline 49 & Potassium 5-keto Gluconate & - & - & - & - & - & - & - & - & - \\
\hline & Catalase Test & - & - & - & - & - & - & - & - & - \\
\hline
\end{tabular}

Table.4 NCBI GeneBank accession number of the identified Lactobacillus isolates

\begin{tabular}{|c|c|c|}
\hline Isolates & $\begin{array}{c}\text { Partially identified by } \\
\text { BLAST }\end{array}$ & $\begin{array}{c}\text { NCBI GeneBank accession } \\
\text { no. }\end{array}$ \\
\hline K3A & Lactobacillus fermentum & KU644575 \\
\hline K4E & Lactobacillus rhamnosus & KX950834 \\
\hline K5 & Lactobacillus fermentum & KU213668 \\
\hline K6 & Lactobacillus fermentum & KU644576 \\
\hline K7 & Lactobacillus fermentum & KU213665 \\
\hline K8 & Lactobacillus plantarum & KX519704 \\
\hline K10 & Lactobacillus plantarum & KU644577 \\
\hline K11 & Lactobacillus plantarum & KU213666 \\
\hline K14 & Lactobacillus helveticus & \\
\hline
\end{tabular}


Fig.1 Ethnic fermented food samples from West Garo Hills, Meghalaya (India)

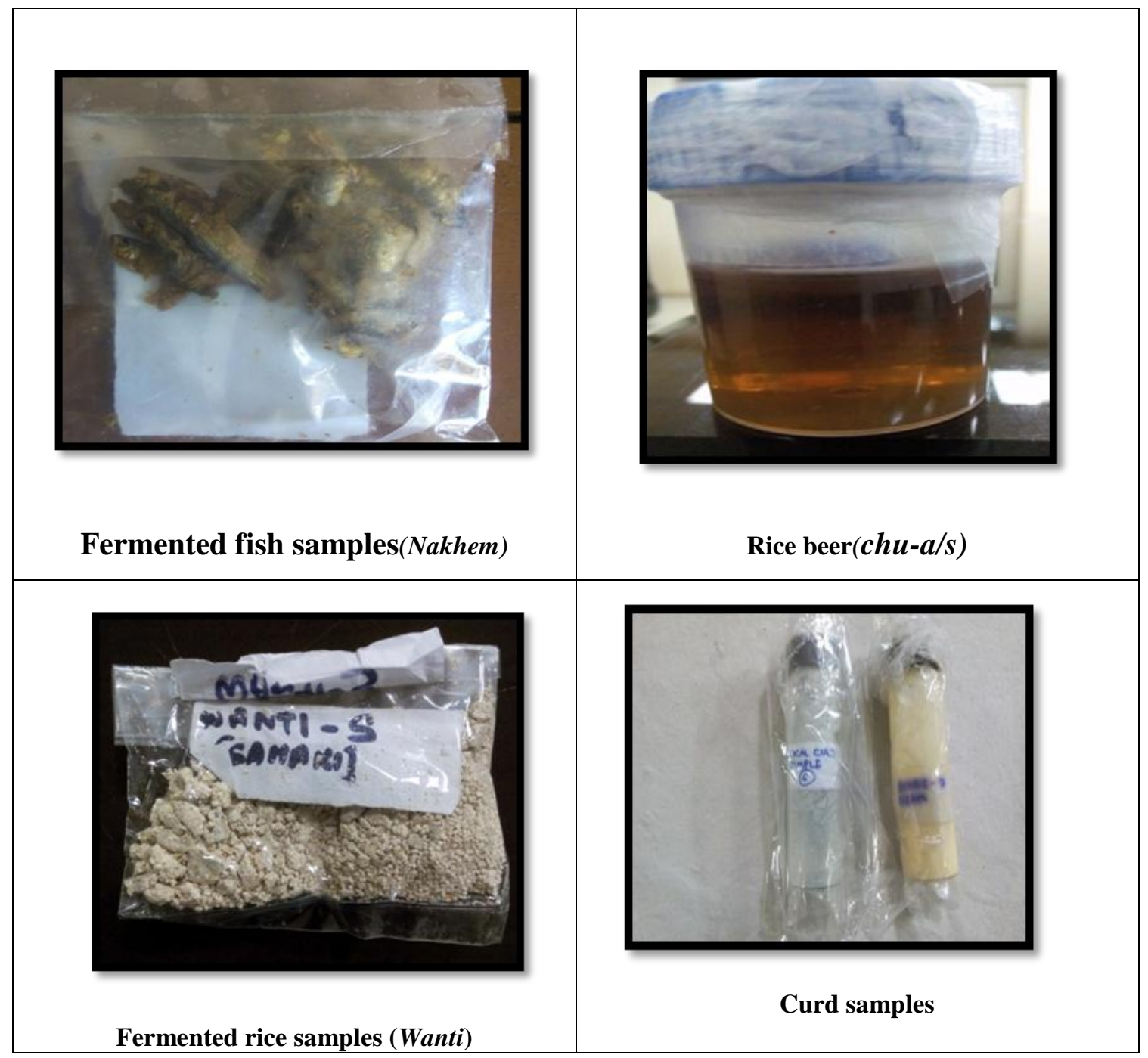

Fig.2 Gram staining of the selected isolates

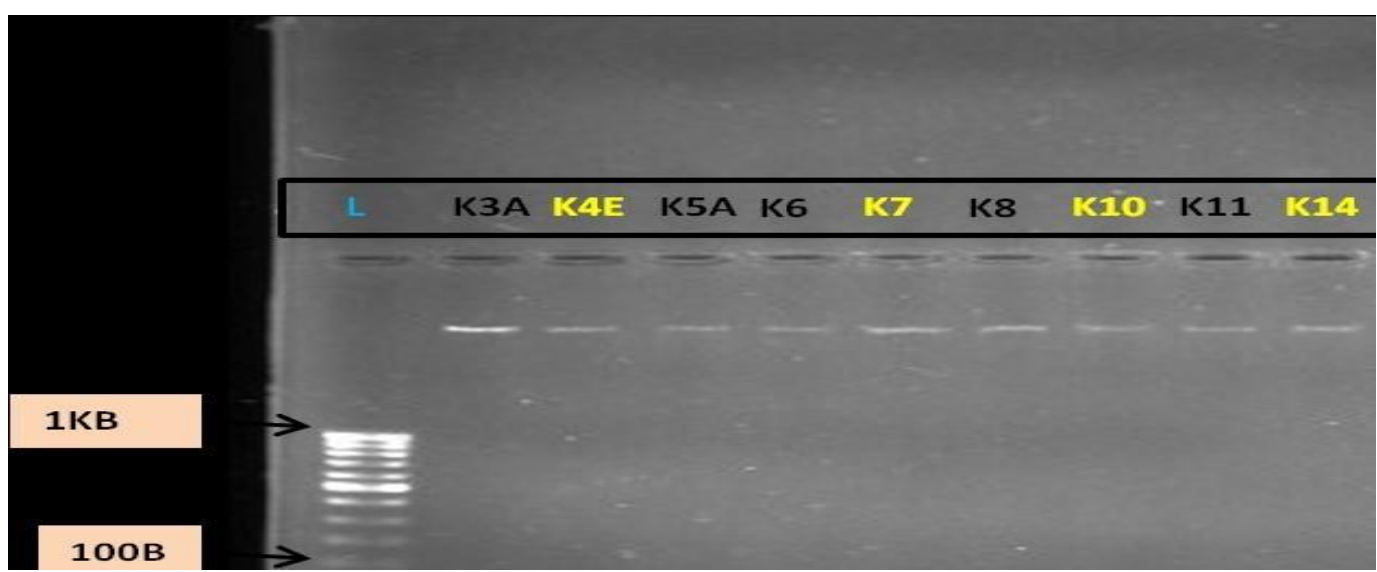


Fig.3 DNA isolation from the selected strains ( $\mathrm{L}=$ Ladder)

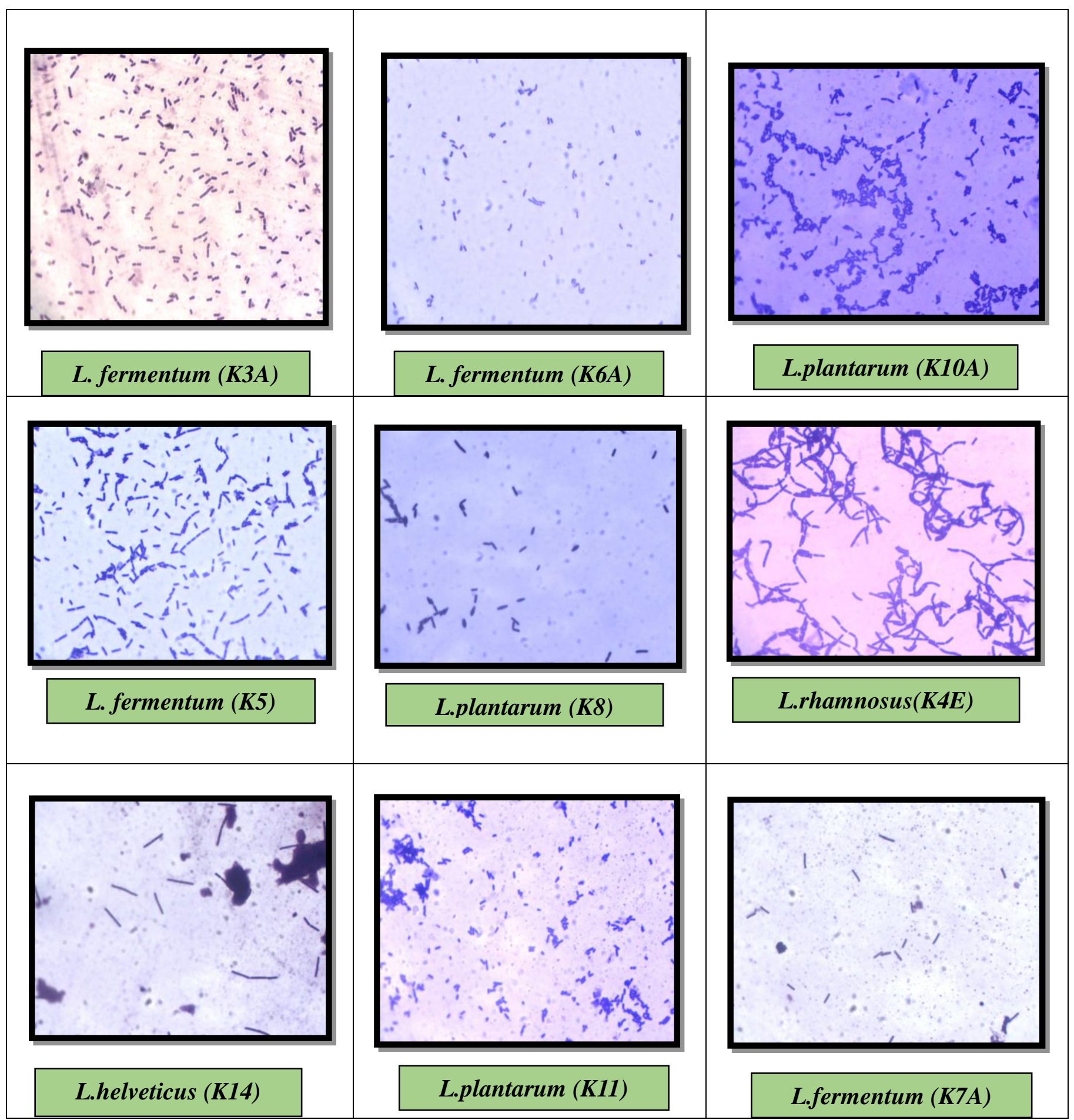


Fig.4 Rooted phylogenetic tree (UPGMA) for Lactobacillus isolates from fermented ethnic foods from Meghalaya

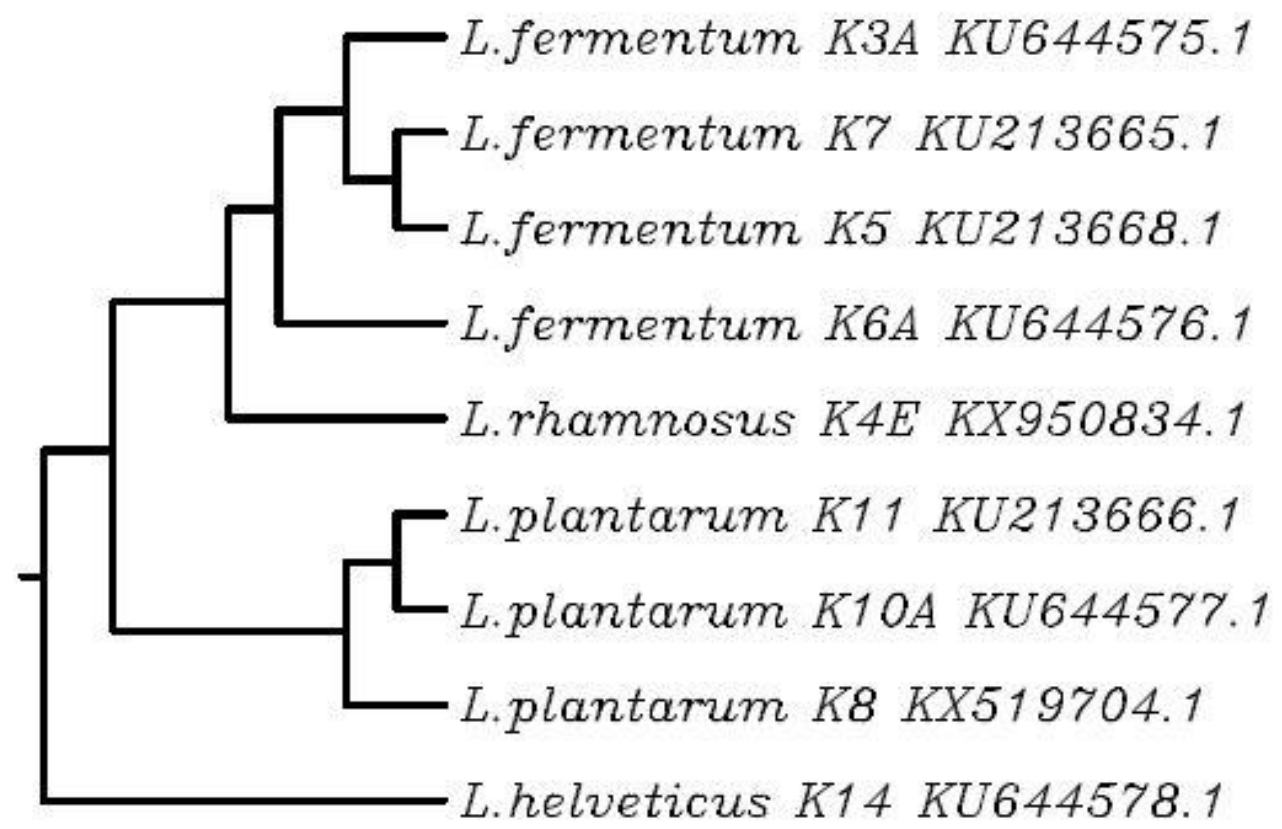

The present study concluded that Lactobacillus spp. were highly predominant in microflora of the various fermented foods from Meghalaya region. The tentative phenotypic identification of the nine isolates (K3A, K4E, K5, K6, K7, K8, K10, K11) were in good concordance with those by the genetic identification which derived that all the strains belonged to Lactobacillus spp. Further 16S rDNA sequence analysis of Lactobacillus strains confirmed the strains as Lactobacillus fermentum (K3A, K7, K5, and K6); Lactobacillus plantarum (K8, K10 and K11); Lactobacillushelveticus (K14) and Lactobacillus rhamnosus (K4E). The evolutionary relatedness were testified by connecting them through a phlyogram. Further, the strains can be checked for their specific probiotic attributes that could be exploited for the development of value added fermented foods in Meghalaya.

\section{Acknowledgement}

The authors are grateful to the Department of Biotechnology (DBT), Ministry of Science and Technology, New Delhi, India for the financial assistance under Twining Project 2013 in collaboration with Anand Agricultural University, Anand, Gujarat and North-Eastern Hill University, Tura Campus, Meghalaya.

\section{References}

Abbas, M.M., and Mahasneh, A.M. 2014. Isolation of Lactobacillus strains with probiotic potential from camel's milk. Afr. J. Microbiol. Res., 8(15): 16451655.

Aderiye, B.I., and Laleye, S.A. 2003. Relevance of fermented food products in southwest Nigeria. Plant Foods for Human Nutri., (Formerly Qualitas 
Plantarum), 3: 1-16.

Adeyemo, S.M., and Onilude, A.A.2014. Molecular identification of Lactobacillus plantarum isolated from fermented cereals. Int. J. Biotechnol. Mol. Biol. Res., 5(6): 59-67.

Agrahar-Murungkar, D., and Subbulakshmi, G. 2006. Preparation techniques and nutritive value of fermented foods from the Khasi tribes of Meghalaya. Ecol. Food and Nutri., 45: 27-38.

Buchanan, R.E., and Gibbons, N.E. 1974. Bergy's Manual of Determentive Bacteriology, $8^{\text {th }}$ edn. (Williams and Wilkins, Baltimore), 1268.

Chelule, P.K., Mokoena, M.P., and Gqaleni, N. 2010. Advantages of traditional lactic acid bacteria fermentation of food in Africa. Current research, technology and education topics in applied microbiology and microbial biotechnology. A. Mendez-Vilas (Ed). FORMATEX, 1162-1167.

Claesson, M.J., Sinderen, D.V., and O'Toole, P.W. $2008 . \quad$ Lactobacillus phylogenomics - towards a reclassification of the genus. Int. J. Systematic and Evol. Microbiol., 58: 2945-2954.

Crispim, S.M., Nascimento, A.M.A., Costa, P.S., Moreira, J.L.S, Nunes, A.C., Nicoli, J.R., Lima, F.L., Mota,V.T., and Nardi, R.M.D. 2013. Molecular identification of Lactobacillus spp. associated with puba, a Brazilian fermented cassava food. Brazilian $J$. Microbiol., 44(1): 15-21.

Das, A.J., and Deka, S.C. 2012. Fermented foods and beverages of the North-East India. Int. Food Res. J., 19(2): 377392.

Devi, K.R., Deka, M. and Jeyaram, K. 2015. Bacterial dynamics during yearlong spontaneous fermentation for production of Ngari, a dry fermented fish product of Northeast India. Int. J.
Food Microbiol., 199: 62-71.

Dilek, O., and Hasibe, C.V. 2011. Identification of Lactobacillus strains isolated from faecal specimens of babies and human milk colostrum by API 50 CHL system. J. Med. Genetics and Genomics, 3(3): 46 - 49.

Ennahar, S., Cai, Y., and Fujita, Y. 2003. Phylogenetic Diversity of Lactic Acid Bacteria Associated with Paddy Rice Silage as Determined by $16 \mathrm{~S}$ Ribosomal DNA Analysis. Appl. Environ. Microbiol., 69(1): 444-451.

Gitanjali, B.S. and Mandal, S. 2015. Fermented products of India and its implication: A review. Asian J. Dairy \& Food Res., 35(1): 1-9.

Guessas, B. and Khal, M. 2004. Characterization of lactic acid bacteria isolated from Algerian arid zone raw goat milk. Afr. J. Biotechnol., 3: 339342.

Jaiswal, V. 2010. Culture and ethnobotany of Jaintia tribal community of Meghalaya, Northeast India - A mini review. Indian J. Traditional Knowledge, 9(1): 38-44.

Krischina, S.A., Jaciara, Z.M., Eunice, C.I., Andréia, Z.D., and Ernani, S.S.A. 2014. Isolation and characterization of lactic acid bacteria and yeasts from the Brazilian grape sourdough. Brazilian J. Pharmaceutical Sci., 50(2): 321327.

Mosha, T.C.E and Vicent, M.M. 2004. Nutritional value and acceptability of homemade maize/sorghum-based weaning mixtures supplemented with rojo bean flour, ground sardines and peanut paste. Int. J. Food Sci. Nutri., 55(4): $301-315$.

Nout, M.J.R., and Sarkar, P.K. 1999. Lactic acid food fermentation in tropical climates. Antonie van Leeuwenhoek, 76: 395-401.

Rahayu, T.H., Gandjar, I., Riani, E., 
Djunaidah, I.S., and Sjamsridzal, A. 2009. Identification and Phylogenetic Analysis of Bacterial Isolates from Litopeanaeus vannamei shrimp culture system and gut enviorment based on 16S rRNA gene sequence data. Microbiol. Indones, 3(2): 56-60.

Sarkar, P., Kumar, L.D.H., Dhumal, C., Panigrahi, S.S., and Choudhary, R. 2015. Traditional and ayurvedic foods of Indian origin. J. Ethn. Foods, 2: 97109.

Steinkraus, K.H. 1996. Handbook of Indigenous Fermented Food. $2^{\text {nd }}$ ed. Marcel Dekker, Inc., New York, NY.
Suk, H.J., Joung, W.P., Cho, I.J., Nam, K.L., In, C.Y., Byung, Y.K., Hye, K.K., and Young, T.H. 2012. Characterization of Lactic Acid Bacteria Isolated from Sauce-type Kimchi. Prev. Nutr. Food Sci., 17: 217-222.

Valcheva, R., Kabadjova, P., Rachman, C., Ivanova, I., Onno, B., Pre' vost, H., and Dousset, X. 2006. A rapid PCR procedure for the specific identification of Lactobacillus sanfranciscensis, based on the 16S23S intergenic spacer regions. J. Appl. Microbiol., 290-302.

\section{How to cite this article:}

Birendra Kumar Mishra, Subrota Hati, Sujit Das and Keyur Patel. 2017. Bio-Diversity of Lactobacillus Cultures Associated with the Traditional Ethnic Fermented Foods of West Garo Hills, Meghalaya, India. Int.J.Curr.Microbiol.App.Sci. 6(2): 1090-1102. doi: http://dx.doi.org/10.20546/ijcmas.2017.602.123 